\title{
Methylxanthines in 100 Brazilian herbs and infusions: determination and consumption
}

\author{
Adriana Dillenburg Meinhart ${ }^{1,2 *}$, Fernanda Mateus Damin², Lucas Caldeirão², Helena Teixeira Godoy ${ }^{2}$ \\ ${ }^{1}$ Federal University of Pelotas, Gomes Carneiro Street, number 01, Pelotas, RS, 96010-610, Brazil, ${ }^{2}$ University of Campinas, Monteiro Lobato \\ Street, number 80, University City Zeferino Vaz, Campinas, SP, 13083-862, Brazil
}

\section{A B S TR A C T}

\begin{abstract}
The contents of caffeine, theophylline and theobromine were studied in 100 plants commercialized in Brazil to investigate new sources of these compounds, and evaluate the consumption of these compounds when these plants are used as infusions (teas). Therefore, two extraction methods were performed, one used an ethanol solution and one used an aqueous infusion process. The extracts were analyzed by ultra-high-performance liquid chromatography. White, green, and black tea (Camellia sinensis) and yerba mate (Ilex paraguariensis) can be considered as potential sources of both caffeine and theobromine. Boldo (Peumus boldus) was a source of theobromine, and smallleaved lime (Tilia cordata), stonebreaker (Phylantus niruri), cow's foot (Bauhinia forficata) and calendula (Calendula officinalis) presented the highest contents of theophylline. This study highlighted herbs not yet investigated for these compounds. The results obtained may be useful in future studies to evaluate the use of these plants as sources of methylxanthines in foods or drugs.
\end{abstract}

Keywords: Caffeine; Plants; Tea; Theophylline; Theobromine

\section{INTRODUCTION}

Methylxanthines are heterocyclic compounds derived from xanthine, characterized by the combination of an imidazole ring and pyrimidinedione, also known as purine alkaloids. These compounds are naturally present in products such as cocoa, coffee, teas and some medicinal herbs. Beverages, such as cola and guarana based soft drinks, also contain methylxanthines. To date, seven methylxanthines have been identified; caffeine, theobromine and theophylline are the most common types (Brunetto et al., 2007; Onãtibia-Astibia et al., 2016; Zacharis et al., 2013).

There are several pharmacological properties that relate methylxanthines to the prevention and/or treatment of respiratory problems such as apnea (Armanian et al., 2015; Mosca et al., 2014), asthma (Makino et al., 2007), and acute or chronic cough (Onãtibia-Astibia et al., 2016). When administered with agomelatine and mianserin (antidepressants), caffeine presented a synergistic effect on the antidepressant activity (Poleszak et al., 2016). Other actions of caffeine include reduced incidence of dyspraxia in children (Doyle et al., 2014), suppressed evolution of glioblastoma (Cheng et al., 2016), and protection against neurodegeneration caused by Parkinson's disease (Xu et al., 2016).

Regarding the stimulant function of caffeine, it stimulates the central nervous system and cardiac activities (Seifert et al., 2011; Trabulo et al., 2011), increasing the physical anbd mental performance, improving the sense of humor and memory (Bizzotto et al., 2013; Malinauskas et al., 2007; Pohler, 2010). Paech et al. (2016) administered caffeine to adults who were kept awake for 50 hours; the results showed that the individuals who received caffeine presented a lower reduction of performance when compared with the control group; however, they did not observe any reduction in the sensation of sleep and tiredness.

On the other hand, when administered in doses above $400 \mathrm{mg} /$ day (considering an adult of $70 \mathrm{~kg}$ ), caffeine may cause anxiety, insomnia (Chaudhary et al., 2016), tachycardia and tremor, among other undesirable symptoms (Reissig et al., 2009). At the dose of $1,000 \mathrm{mg} /$ day and above, it causes body toxicity, and from 5,000 to $10,000 \mathrm{mg} /$ day, it may be lethal (Seifert et al., 2011).

\footnotetext{
${ }^{*}$ Corresponding author:

Adriana Dillenburg Meinhart, Federal University of Pelotas, Gomes Carneiro Street, number 01, Pelotas, RS, 96010-610, Brazil.

E-mail: adrianadille@gmail.com
}

Received: 01 December 2018 ; $\quad$ Accepted: 11 February 2019 
Theobromine and theophylline have antioxidant activity, presenting positive influence to suppress oxidative stress. Both compounds been used medically to promote diuresis, relaxation of bronchial muscle and excitation of the nervous and circulatory systems (Wu, et al, 2019). It has been shown that theobromine seems to be toxic to some animal models, including pets, however, a large number of clinical trials proved that for humans, there is no toxic effect (Martínez-Pinilla, et al 2015). van Zyl, et al, (2008) have even concluded that the use of theobromine, instead of other drugs including caffeine, to treat respiratory diseases generates higher diffusion in lung structures.

Several plant matrixes are used in Brazilian popular medicine, especially in the form of infusion, popularly known as tea, to help in the treatment of several diseases (Bieski et al., 2015; Dutra et al., 2016; Leitão et al., 2014). The Brazilian Ministry of Health, through its 'National Policy on Integrative and Complementary Practices of SUS', has encouraged the use of herbs as one form of access to alternative and complementary medications (Brasil, 2006).

Due to the different applications, effects of methylxanthines and the expressive consumption of plant infusions in Brazil, it is extremely important to know the content of methylxanthines in these plants. Even though there are several studies that quantified xanthines, we did not find a study comparing a large variety of plants used in the preparation of infusion using the same method of extraction, making it difficult, therefore, to have comparative studies among plants. The objective of this study was to quantify theobromine, theophylline and caffeine in herbs commercialized in Brazil, searching for new sources of methylxanthines, and to estimate the consumption of these compounds when these plants are used for the preparation of infusions.

\section{MATERIAL AND METHODS}

\section{Samples and reagents}

The samples of the plants were acquired in public markets and street fairs in the cities of Campinas and Americana, in the state of São Paulo, Brazil, each from three different suppliers.

Caffeine, theophylline and theobromine standards were obtained from Sigma Aldrich (St. Louis, USA). The water used in the experiments was ultra-purified in Milli- $Q^{\circledR}$ system from Millipore (Kankakee, USA). Formic acid was obtained from Merck (São Paulo, Brazil), chromatographic grade acetonitrile from JT Backer (Goiânia, Brazil) and ethanol P.A. from Synth (Diadema, Brazil). All solutions were filtered through PVDF membranes of $0.22 \mu \mathrm{m}$ porosity from Millipore (Kankakee, USA).

\section{Sample preparation}

About $40 \mathrm{~g}$ of sample from the three suppliers were homogenized and milled in a hammer mill (Marconi TE 600, Piracicaba, Brazil), on a 200 mesh porosity sieve. The extraction of methylxanthines was made through two methods: one with ethanol: water solution and one with a hot aqueous infusion, simulating the traditional popular preparation.

The extraction with the ethanol solution was performed according to Meinhart et al., 2017. About $0.5 \mathrm{~g}$ of milled sample was weighed and $15 \mathrm{~mL}$ of extractive solution $(74 \%$ water: $26 \%$ ethanol) were added to hermetically sealed tubes. The tubes were placed in a water bath at $60^{\circ} \mathrm{C}$ and shaken at $240 \mathrm{rpm}$ (rotations per minute) for 22 minutes. After that, the volume was measured, the extracts were filtered and then injected. Only the samples that presented the concentration of methylxanthines above the quantification limit were submitted to the infusion extraction.

For the aqueous extraction, it was used a form of preparation usually used by Brazilian consumers and also described by da Silveira et al., 2014 as the best preparation for the extraction of phenolic compounds. For this purpose, $300 \mathrm{ml}$ of boiling water (amount equivalent to a mug) were added to $2 \mathrm{~g}$ of the sample (amount equivalent to a commercial sachet); the solution remained in infusion for 16 minutes. Then, the mixture was cooled, the volume was measured, and the extracts were filtered and injected.

\section{Methylxanthine analysis method}

An ultra-efficient liquid chromatography (UPLC) Acquity ${ }^{\circledR}$ (Waters, Morganville, USA) equipment was used with a diode arrangement detector. The column was a C18 Kinetex ${ }^{\circledR}$, $100 \mathrm{~mm}$ long, $2.1 \mathrm{~mm}$ internal diameter, and $1.7 \mu \mathrm{m}$ particle size (Phenomenex, Torrance, USA), with mobile phases and gradient as described by Meinhart et al., 2017. The compounds were identified by comparison with standards through the retention time, DAD absorption spectrum at $274 \mathrm{~nm}$, and by co-chromatography. The method was validated and data was analyzed with the software Statistica 7.0 (Statsoft, Tulsa, USA).

\section{Evaluation of consumption and comparison with other foods and beverages}

From the results obtained in the aqueous infusions, the content of methylxanthines was estimated in home measures to estimate how much is consumed. In addition, the contents were correlated with other foods and beverages reported in the literature.

\section{RESULTS AND DISCUSSION}

\section{Analytical method validation}

The limits of detection and quantification (evaluated as three and six times the signal-noise intensity) were adequate, 
with the quantification limit smaller than $0.06 \mathrm{mg} \mathrm{L}^{-1}$. The precision values (within the day and between days) were lower than $6.6 \%$ for all levels (limit of quantification, intermediate concentration and maximum concentration of the curve). The linear range was adequate and did not present lack of adjustment, with $\mathrm{F}$ values lower than the critical $\mathrm{F}$ (3.49), with $95 \%$ confidence. The parameters observe the limits issued by IUPAC (2002), showing that it is recommended for quantitative analyses with analytical safety. Fig 1 show HPLC analysis results of standard, water-extracted, and ethanol-extracted samples of Ilex paraguariensis sample.

\section{Theobromine}

Table 1 shows the content of methylxanthines determined in samples. Out of the 100 samples, 61 presented at least one of the methylxanthines analyzed in this study; the samples that did not result in quantifiable concentrations are presented at the end of the Table 2.

Regarding the content of theobromine extracted by ethanol as a ethanol solution, 29 samples presented concentration between $1.45 \mathrm{mg} \mathrm{kg}^{-1}$ [pennyroyal, (Mentha pylegium)] and $895.79 \mathrm{mg} \mathrm{kg}^{-1}$ [yerba mate (Ilex paraguariensis)]; of these, 24 samples showed contents below $66.55 \mathrm{mg} \mathrm{kg}-1$ and only five presented values above $200.00 \mathrm{mg} \mathrm{kg}^{-1}$ : boldo (Peumus boldus), black, white and green tea (Camellia sinensis) and yerba mate (Ilex paraguariensis). Several studies reported the identification and quantification of theobromine in Camellia sinensis (Wang et al., 2011; Zielinski et al., 2016) and yerba mate (Meinhart et al., 2010; Urfer et al., 2002); however, the authors did not find in the literature studies that correlated boldo with theobromine.

When the extraction was performed with water and infusion process, only 26 samples presented quantifiable concentration of theobromine, since the values were between $1.49 \mathrm{mg} \mathrm{kg}^{-1}$ for arnica (Arnicae flos) and $837.95 \mathrm{mg} \mathrm{kg}^{-1}$ for yerba mate. Only the samples of Camellia sinensis (black, green and white tea) and yerba mate presented concentrations above $200 \mathrm{mg} \mathrm{kg}^{-1}$. The extraction methods presented a small difference (between $0.7 \%$ and $7 \%$ ) for black tea, white tea and yerba mate; however, the quantification of theobromine in boldo and green tea through infusion extraction was $55.86 \mathrm{mg} \mathrm{kg}^{-1}$ and $612.49 \mathrm{mg} \mathrm{kg}^{-1}$, respectively, that is, $293 \%$ and $34 \%$ lower than when using extraction with ethanol.

These results show a low content of theobromine in the samples and the potential of boldo, black, white and green tea and yerba mate as an accessible sources of theobromine.

\section{Theophylline}

Only 11 samples presented quantifiable concentrations of this compound. These results showed that theophylline was the least abundant compound in the samples. The content of this compound in the samples extracted with ethanol were between $0.69 \mathrm{mg} \mathrm{kg}^{-1}$ for ginseng (Panax ginseng) and $47.65 \mathrm{mg} \mathrm{kg}^{-1}$ for small-leaved lime (Tilia cordata). Stonebreaker (Phylantus niruri) and cow's foot (Bauhinia forficata) also presented high contents of theophylline, $38.42 \mathrm{mg} \mathrm{kg}^{-1}$ and $30.71 \mathrm{mg} \mathrm{kg}^{-1}$, respectively. This study presents unpublished results in terms of determination of the content of theophylline in small-leaved lime, stonebreaker and cow's foot, and, consequently, the identification of these plants as potential sources of this compound in the 100 analyzed plants.

Unlike theobromine, all samples with quantifiable concentrations of theophylline through ethanol extraction also presented contents of this compound when the extraction was performed by infusion; fennel (Foeniculum vulgare) was the sample with the lowest content of theophylline $\left(1.65 \mathrm{mg} \mathrm{kg}^{-1}\right)$ and small-leaved lime presented the highest content $\left(50.46 \mathrm{mg} \mathrm{kg}^{-1}\right)$ through aqueous infusion.

Only four samples presented a difference below 10\% when comparing the extraction methods: small-leaved lime [Tilia cordata (5.5\%)], stonebreaker [Phylantus niruri $(9.0 \%)$, calendula [Canlendula officinallis $(2.2 \%)]$ and mint [Mentha sp (8.9\%)]. Husks of jatoba (Hymenaea courabril) presented $250 \%$ more theophylline through the ethanol extraction versus infusion method, and ginseng presented $72 \%$ more theophylline through the infusion method. These results confirm that the extraction method is specific for each matrix and, for this reason, individual studies are required to optimize the extraction of xanthine compounds.

\section{Caffeine}

Caffeine was the most frequent methylxanthine in the analyzed samples, with $55 \%$ of the plants presenting quantifiable concentrations. The levels ranged from $0.65 \mathrm{mg} \mathrm{kg}^{-1}$ for ginseng to $9,544.87 \mathrm{mg} \mathrm{kg}^{-1}$ for black tea. However, 30 samples presented a content below $10.00 \mathrm{mg} \mathrm{kg}^{-1}, 15$ samples presented concentrations between $10.10 \mathrm{mg} \mathrm{kg}^{-1}$ and $30.00 \mathrm{mg} \mathrm{kg}^{-1}, 6$ samples between $30.10 \mathrm{mg} \mathrm{kg}^{-1}$ and $100.00 \mathrm{mg} \mathrm{kg}^{-1}$, and only 4 samples were potential sources of caffeine: black tea [Camellia sinensis $\left.\left(9,544.84 \mathrm{mg} \mathrm{kg}^{-1}\right)\right]$, green tea [Camellia sinensis $\left(5,190.72 \mathrm{mg} \mathrm{kg}^{-1}\right)$ ], yerba mate [Ilex paraguariensis $\left.\left(5,132.43 \mathrm{mg} \mathrm{kg}^{-1}\right)\right]$, and white tea [Camellia sinensis $\left.\left(2,654.83 \mathrm{mg} \mathrm{kg}^{-1}\right)\right]$.Several studies identified and quantified caffeine in Camellia sinensis (Lin et al., 1998; Mizukami et al., 2007; Samanidou et al., 2012; Wang et al., 2011; Yang et al., 2007; Zielinski et al., 2016), and in yerba mate (Bassani et al., 2014; Murakami et al., 2013; Urfer et al., 2002). 


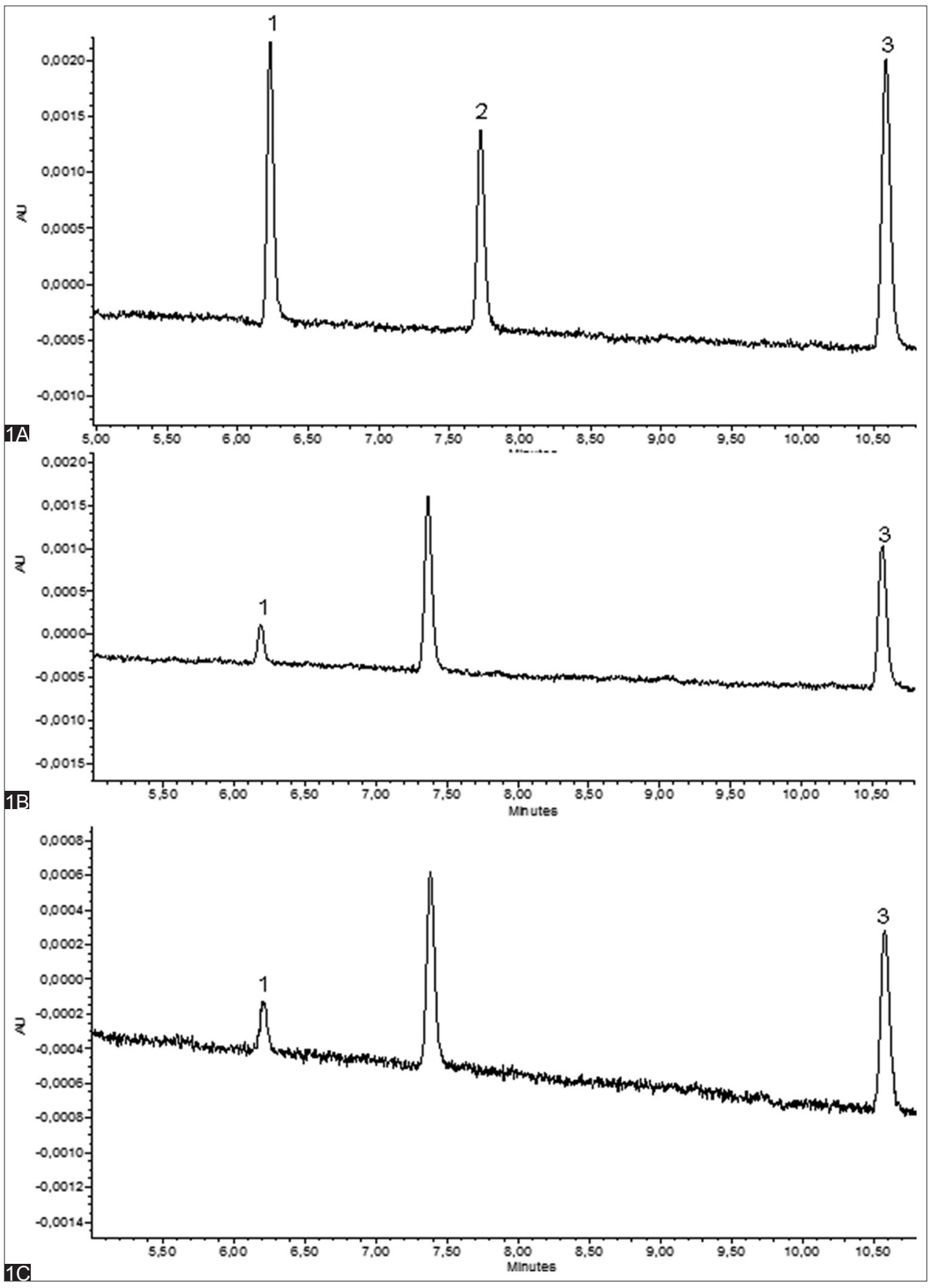

Fig 1. HPLC analysis results of standards. (1A), etanol-extracted (1B) and water-extracted (1C) of Ilex paraguariensis sample. Compounds: 1: Theobromine; 2: Theophylline; 3: Caffeine

The aqueous infusion process extracted caffeine from 49 samples at quantifiable levels, ranging from $2.28 \mathrm{mg} \mathrm{kg}^{-1}$ for jalapa (Operculina alata) to $6,979.90 \mathrm{mg} \mathrm{kg}^{-1}$ for black tea (Camellia sinensis). Catss claw(Acacia plumosa), cuphea (Cuphea ingrata), black sage (Cordia verbenácea), buckthorn (Rhamnus purshiana), greater burdock (Arctium lappa), and maidenhair (Adiantum capillus-veneris), unlike the result from the ethanol extraction, did not present a quantifiable content of the compound in the aqueous extraction. As in the ethanol extraction, white tea $\left(2,751.53 \mathrm{mg} \mathrm{kg}^{-1}\right)$, green tea $\left(3,740.88 \mathrm{mg} \mathrm{kg}^{-1}\right)$, yerba mate $\left(4,800.95 \mathrm{mg} \mathrm{kg}^{-1}\right)$, and black tea $\left(6,979.90 \mathrm{mg} \mathrm{kg}^{-1}\right)$ were the samples with the highest contents of caffeine in the aqueous infusion.

In the comparison between the extraction methods, the difference between them does not have a trend, that is, it is characteristic for each sample, ranging between $0.3 \%$ (winterss bark) and 177\% (boldo). The difference between the extraction methods for the main sources of caffeine in this study was 3\% for white tea, 7\% for yerba mate, $37 \%$ for black tea, and 39\% for green tea. 


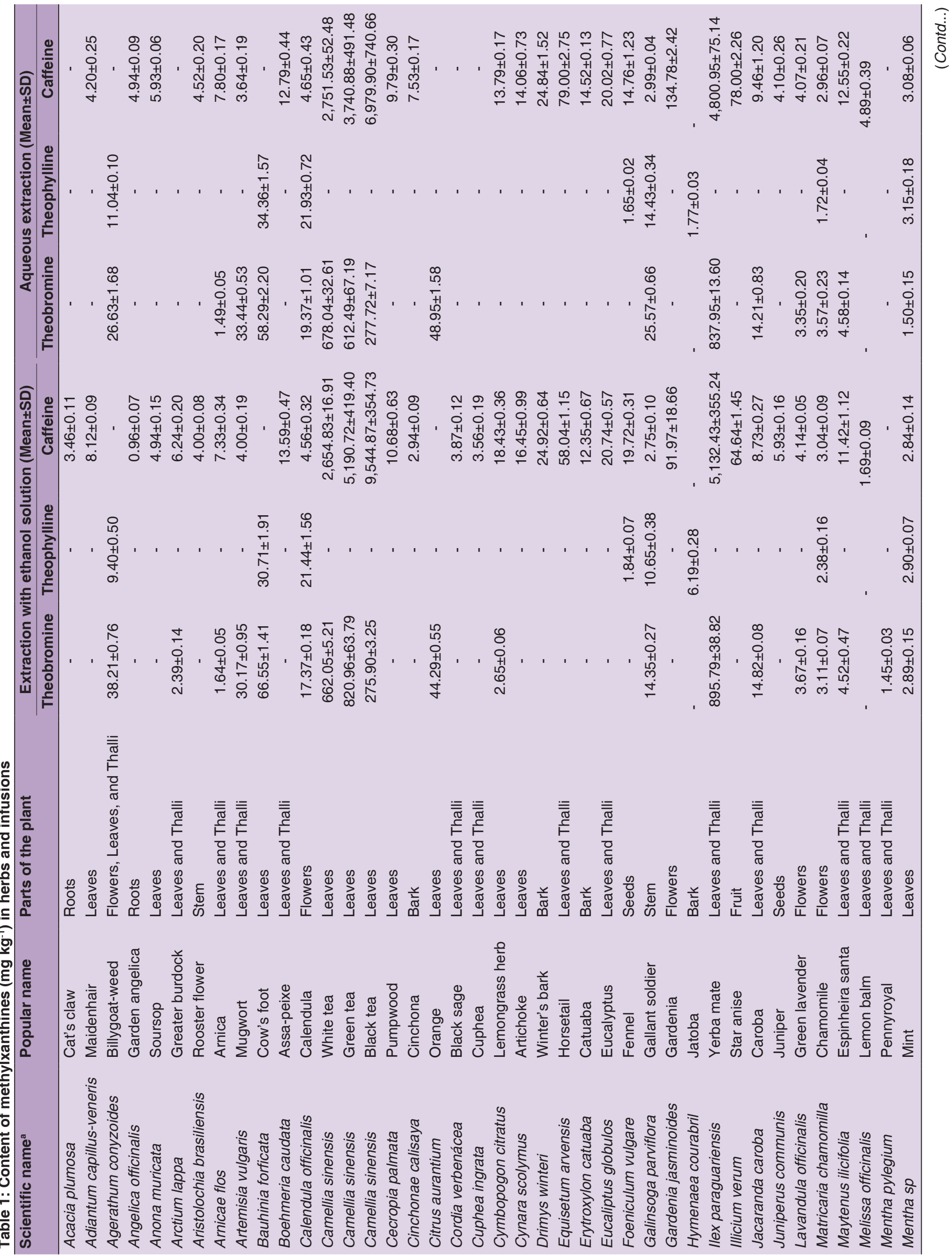




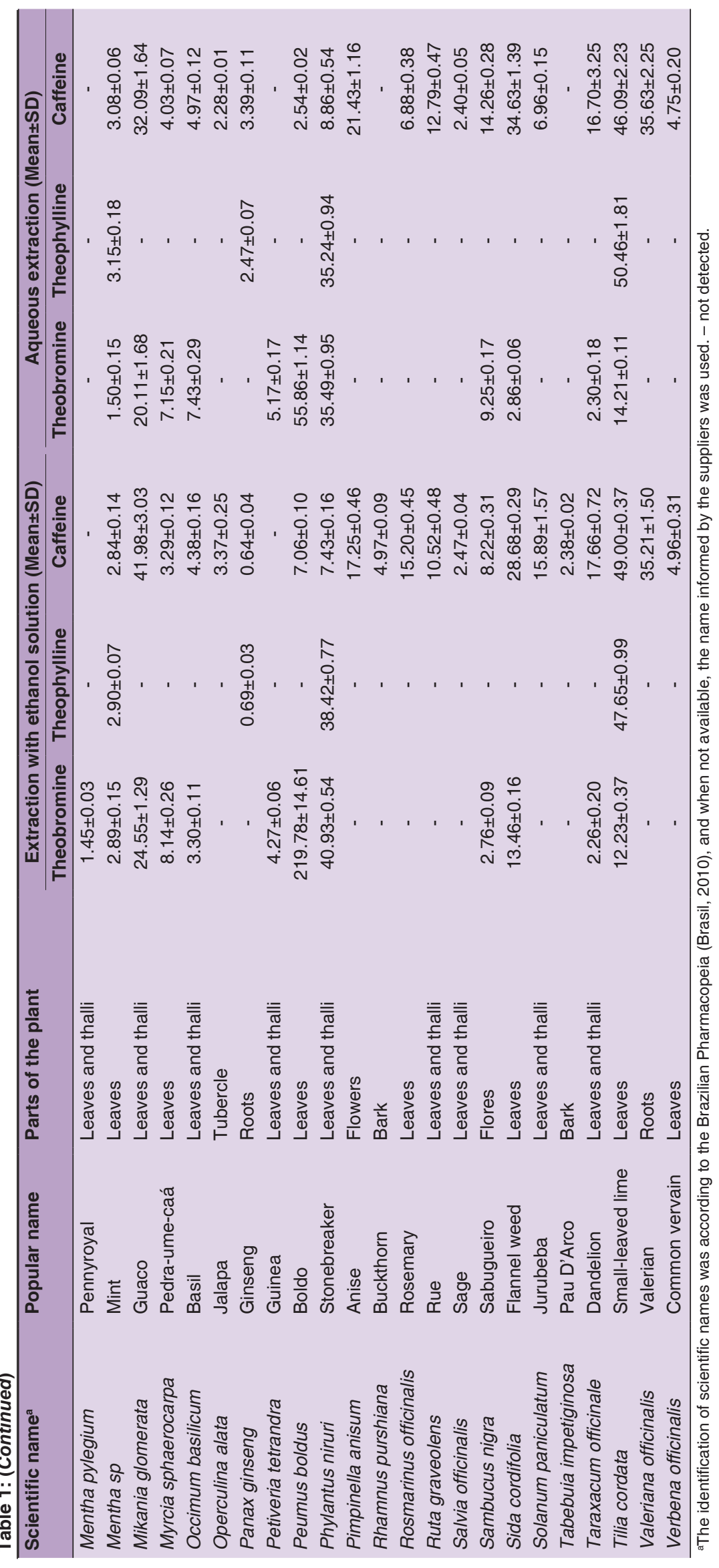


Table 2: Plants with non-detected amounts in the extraction with ethanol solution

\begin{tabular}{|c|c|c|}
\hline Scientific name ${ }^{a}$ & Popular name & Parts of the plant \\
\hline Anadenanthera colubrina & Angico & Bark \\
\hline Artemisia absinthum & Wormwood & Leaves and thalli \\
\hline Baccharis trimera & Carqueja & Leaves and thalli \\
\hline Bidens Pilosa & Black-jack & Leaves and thalli \\
\hline Bixa Orellana & Achiote & Seeds \\
\hline Casearia sylvestris & Guaçatonga & Leaves and thalli \\
\hline Chenopodium ambrosioides & Wormseed & Leaves, thalli, and seeds \\
\hline Chododendron platyphyllum & Abútua & Stem \\
\hline Cinnamomum cassia & Cinnamon & Bark \\
\hline Cirsium vulgare & Common thistle & Leaves and thalli \\
\hline Cordia salicifolia & Porangabae & Leaves and thalli \\
\hline Cordia sellowiana & Chá de bugre & Leaves \\
\hline Costus spicatus & Spiked spiralflag ginger & Leaves \\
\hline Echinodorus grandiflorus & Chapéu de couro & Leaves and thalli \\
\hline Fevillea trilobata & Andiroba & Seeds \\
\hline Glycyrhiza glabra & Liquorice & Stem \\
\hline Hibiscus sabdariffa & Roselle & Flowers \\
\hline Hydrocotyle asiatica & Centella asiatica & Leaves and thalli \\
\hline Lavandula officinalis & Lavender & Flowers and leaves \\
\hline Medicago sativa & Alfalfa & Leaves and thalli \\
\hline Myracrodruon urundeuva & Aroeira & Bark \\
\hline Myroxylon peruiferum & Bálsamo do norte & Bark \\
\hline Ocotea preciosa & Sassafraz & Stem \\
\hline Passiflora alata & Passion fruit & Leaves and thalli \\
\hline Persea gratíssima & Avocado & Leaves \\
\hline Plantago major & Broadleaf plantain & Leaves and thalli \\
\hline Polygonum acre & Water Pepper & Leaves and thalli \\
\hline Ptychopetalum olacoides & Muira Puama & Stem \\
\hline Punica granathum & Pomegranate & Bark \\
\hline Quassia amara & Bitter-ash & Stem \\
\hline Senna alexandrina & Egyptian senna & Leaves \\
\hline Smilax salsaparrilha & Sarsaparilla & Stem \\
\hline Stryphnodendron adstringen & Barbatimão & Bark \\
\hline Symphytum asperum & Comfrey & Leaves and thalli \\
\hline Trichilia catigua & Catuaba & Stem \\
\hline Urtica dioica & Common nettle & Leaves \\
\hline Verbena bonariensis & Vervain & Stem \\
\hline Zea mays & Corn silk & Corn silk \\
\hline Ziziphus joazeiro & Juá & Bark \\
\hline
\end{tabular}

aThe identification of scientific names was according to the Brazilian Pharmacopeia (Brasil, 2010), and when not available, the name informed by the suppliers was used.

\section{Intake of methylxanthines and comparison with other foods and beverages}

Considering one serving $(300 \mathrm{~mL})$ of infusion, prepared with $2 \mathrm{~g}$ of the main plants presented in this study, the intake of methylxanthines was estimated. One serving of infused mate tea has $9.60 \mathrm{mg}$ of caffeine and $1.66 \mathrm{mg}$ of theobromine, while the same serving of white tea has $5.50 \mathrm{mg}$ of caffeine and $1.35 \mathrm{mg}$ of theobromine. Black tea has $13.96 \mathrm{mg}$ of caffeine, $0.55 \mathrm{mg}$ of theobromine, while green tea has $7.48 \mathrm{mg}$ of caffeine and $1.22 \mathrm{mg}$ of theobromine. As for theophylline, the same serving of infusion of small-leaved lime, stonebreaker, cow's foot and calendula have $0.10 \mathrm{mg}$, $0.07 \mathrm{mg}, 0.07 \mathrm{mg}$, and $0.04 \mathrm{mg}$, respectively.
Considering the dose of $120 \mathrm{mg}$ per day ${ }^{-1}$ as a small intake of caffeine [17], an adult should take around $30 \mathrm{~mL}$ of coffee (Rodrigues and Bragagnolo, 2013) or $125 \mathrm{~g}$ of chocolate with $42 \%$ cocoa (Peralta-Jiménez and CañizaresMacías, 2013) or $380 \mathrm{~mL}$ of an energy drink (Rostagno et al., 2011) or, according to the findings of this study, $2,570 \mathrm{~mL}$ of black tea.

For the same amount of theobromine, one would have to take $11 \mathrm{~g}$ of chocolate with $42 \%$ cocoa or $245 \mathrm{~g}$ of milk chocolate, $350 \mathrm{~mL}$ of chocolate beverage (Peralta-Jiménez and Cañizares-Macías, 2013) or 21,600 mL of yerba mate infusion, which is equivalent to 72 servings of $300 \mathrm{~mL}$ each. 
Comparatively, a cup of coffee $(50 \mathrm{~mL})$ has around $0.35 \mathrm{mg}$ of theophylline (Rodrigues and Bragagnolo, 2013), which is equivalent to $1,050 \mathrm{~mL}$ of small-leaved lime infusion or 1,500 mL of infusion of stonebreaker or cow's foot, or $2,400 \mathrm{~mL}$ of calendula infusion. Despite the low concentration of theophylline, this finding is relevant for people who have some degree of sensitivity to caffeine, since these plants have little or no concentration of this compound.

\section{CONCLUSION}

This study presented a screening of new sources of methylxanthines (caffeine, theophylline and theobromine) in 100 plants consumed in Brazil, of which, several have not been analyzed for this subject. Among the plants studied, $39 \%$ did not present any content of methylxanthines at quantifiable levels. The plants with the highest amount of caffeine were: black tea, green tea, yerba mate and white tea, for theobromine: yerba mate, green tea, white tea, black tea and boldo, and for theophylline: small-leaved lime, stonebreaker, cow's foot and calendula. The content of methylxanthines was lower when compared with other foods and beverages; however, the consumption of infusions is usually in larger amounts, which may contribute to the increased intake of these compounds. From the results obtained it was possible to evaluate the concentration of methylxanthines in herbs commercialized in Brazil and evaluate the exposure and consumption of methylxanthines when these plants are destined to the preparation of infusions. The data obtained allows the elaboration of future studies on bioaccessibility and bioavailability of methylxanthines for use of these plants in food and drugs.

\section{Conflict of interest and funding}

The Author(s) declare(s) that there is no conflict of interest. This work was supported by the Coordination for Higher Education Staff Development (CAPES, No 1267386). The plant research was registered with the Ministry of the Environment of Brazil (number A3414AD).

\section{Authors' contributions}

All authors contributed equally to the planning and execution of the research.

\section{REFERENCES}

Armanian, A. M., R. Iranpour, E. Faghihian, and N. Salehimehr. 2015. Caffeine administration to prevent apnea in very premature infants. Pediatr. Neonatol. 57: 5-9.

Bassani, D. C., D. S. Nunes and D. Granato. 2014. Optimization of phenolics and flavonoids extraction conditions and antioxidant activity of roasted yerba-mate leaves (Ilex paraguariensis A. St.Hil., Aquifoliaceae) using response surface methodology. An. Acad. Bras. Cienc. 86: 923-933.
Bieski, I. G. C., M. Leonti, J. T. Arnason, J. Ferrier, M. Rapinski, I. M. P. Violante and D. T. De Oliveira Martins. 2015. Ethnobotanical study of medicinal plants by population of valley of Juruena region, legal amazon, Mato Grosso, Brazil. J. Ethnopharmacol. 173: 383-423.

Bizzotto, C. S., A. D. Meinhart, C. A. Ballus, G. Ghiselli and H. T. Godoy. 2013. Comparison of capillary electrophoresis and high performance liquid chromatography methods for caffeine determination in decaffeinated coffee. Food Sci. Technol. 33: 186-191.

Brasil. 2006. Política nacional de práticas integrativas e complementares no SUS: Uma ação de inclusão. In: M. da Saúde, (Ed.), Ciência and Saúde Coletiva. Vol. 11. Ministério da Saúde, Brasília.

Brasil. 2010. Farmacopéia Brasileira. $5^{\text {th }}$ ed., Vol. 1. Agência Nacional de Vigilância Sanitária, Brasília.

Del Brunetto, M. R., L. Gutierrez, Y. Delgado, M. Gallignani, A. Zambrano, A. Gimez and C. Romero. 2007. Determination of theobromine, theophylline and caffeine in cocoa samples by a high-performance liquid chromatographic method with on-line sample cleanup in a switching-column system. Food Chem. 100: 459-467.

Chaudhary, N. S., M. A. Grandner, N. Jackson and S. Chakravorty. 2016. Caffeine consumption, insomnia and sleep duration: Results from a nationally representative sample. Nutrition. 32: 11-12.

Cheng, Y. C., Y. M. Ding, D. Y. Hueng, J. Y. Chen and Y. Chen. 2016. Caffeine suppresses the progression of human glioblastoma via cathepsin B and MAPK signaling pathway. J. Nutr. Biochem. 33: 63-72.

Da Silveira, T. F. F., A. D. Meinhart, C. A. Ballus and H. T. Godoy. 2014. The effect of the duration of infusion, temperature, and water volume on the rutin content in the preparation of mate tea beverages: An optimization study. Food Res. Int. 60: 241-245.

Doyle, L. W., B. Schmidt, P. J. Anderson, P. G. Davis, D. Moddemann, R. E. Grunau and R. Roberts. 2014. Reduction in developmental coordination disorder with neonatal caffeine therapy. J. Pediatr. 165(2): 356-359.

Dutra, R. C., M. M. Campos, A. R. S. Santos and J. B. Calixto. 2016. Medicinal plants in Brazil: Pharmacological studies, drug discovery, challenges and perspectives. Pharmacol. Res. 112: 4-29.

Leitão, F., S. G. Leitão, V. S. da Fonseca-Kruel, I. M. Silva and K. Martins. 2014. Medicinal plants traded in the open-air markets in the state of Rio de Janeiro, Brazil: An overview on their botanical diversity and toxicological potential. Braz. J. Pharmacogn. 24: 225-247.

Lin, J. K., C. L. Lin, Y. C. Liang, S. Y. Lin-Shiau and I. M. Juan. 1998. Survey of catechins, gallic acid, and methylxanthines in green, oolong, pu-erh, and black teas. J. Agric. Food Chem. 46: 3635-3642.

Makino, S., M. Fueki and N. Fueki. 2007. Efficacy and safety of methylxanthines in the treatment of asthma. Yearb. Pulm. Dis. 2007: 23.

Malinauskas, B. M., V. G. Aeby, R. F. Overton, T. CarpenterAeby and K. Barber-Heidal. 2007. A survey of energy drink consumption patterns among college students. Nutr. J. 6: 35.

Martínez-Pinilla, E., A. Oñatibia-Astibia and R. Franco. 2015. The relevance of the obromine for the beneficial effects of cocoa consumption. Front. Pharmacol. 6: 1-5.

Meinhart, A. D., C. S. Bizzotto, C. A. Ballus, A. C. P. Rybka, M. R. Sobrinho, R. S. Cerro-Quintana and H. T. Godoy. 2010 Methylxanthines and phenolics content extracted during the 
consumption of mate (Ilex paraguariensis St. Hil) beverages. J. Agric. Food Chem. 58: 2188-2193.

Meinhart, A. D., F. M. Damin, L. Caldeirão, T. F. F. da Silveira, J. T. Filho and H. T. Godoy. 2017. Chlorogenic acid isomer contents in 100 plants commercialized in Brazil. Food Res. Int. 99: 522-530.

Mizukami, Y., Y. Sawai and Y. Yamaguchi. 2007. Simultaneous analysis of catechins, gallic acid, strictinin, and purine alkaloids in green tea by using catechol as an internal standard. J. Agric. Food Chem. 55: 4957-4964.

Mosca, E. V., P. Ciechanski, A. Roy, E. C. Scheibli, K. Ballanyi and R. J. A. Wilson. 2014. Methylxanthine reversal of opioid-induced respiratory depression in the neonatal rat: Mechanism and location of action. Respir. Physiol. Neurobiol. 200: 80-89.

Murakami, A. N. N., R. D. D. Amboni, E. S. Prudêncio, E. R. Amante, C. B. Fritzen-Freire, B. C. B. Boaventura and M. Maraschin. 2013. Concentration of biologically active compounds extracted from Ilex paraguariensis St. Hil. By nanofiltration. Food Chem. 141: 60-65.

Onãtibia-Astibia, A., E. Martínez-Pinilla and R. Franco. 2016. The potential of methylxanthine-based therapies in pediatric respiratory tract diseases. Respir. Med. 112: 1-9.

Paech, G. M., S. Banks, M. Pajcin, C. Grant, K. Johnson, G. H. Kamimori and C. B. Vedova. 2016. Caffeine administration at night during extended wakefulness effectively mitigates performance impairment but not subjective assessments of fatigue and sleepiness. Pharmacol. Biochem. Behav. 145: 27-32.

Peralta-Jiménez, L. and M. P. Cañizares-Macías. 2013. Ultrasoundassisted method for extraction of theobromine and caffeine from cacao seeds and chocolate products. Food Bioprocess Technol. 6: 3522-3529.

Pohler, H. 2010. Caffeine intoxication and addiction. J. Nurse Pract. 6: 49-52.

Poleszak, E., A. Szopa, E. Wyska, W. Kukula-Koch, A. Serefko, S. Wosko and P. Wlaz. 2016. Caffeine augments the antidepressant-like activity of mianserin and agomelatine in forced swim and tail suspension tests in mice. Pharmacol. Rep. 68: 56-61.

Reissig, C. J., E. C. Strain and R. R. Griffiths. 2009. Caffeinated energy drinks-a growing problem. Drug Alcohol Depend. 99: 1-10.

Rodrigues, N. P. and N. Bragagnolo. 2013. Identification and quantification of bioactive compounds in coffee brews by HPLCDAD-MSn. J. Food Compos. Anal. 32: 105-115.

Rostagno, M. A., N. Manchon, M. D'Arrigo, E. Guillamon, A. Villares, A. Garcia-Lafuente and J. A. Martinez. 2011. Fast and simultaneous determination of phenolic compounds and caffeine in teas, mate, instant coffee, soft drink and energetic drink by high-performance liquid chromatography using a fused-core column. Anal. Chim. Acta. 685: 204-211.

Samanidou, V., A. Tsagiannidis and I. Sarakatsianos. 2012. Simultaneous determination of polyphenols and major purine alkaloids in Greek Sideritis species, herbal extracts, green tea, black tea, and coffee by high-performance liquid chromatography-diode array detection. J. Sep. Sci. 35: 608-615.

Seifert, S. M., J. L. Schaechter, E. R. Hershorin, S. E. Lipshultz and S. E. Lipshultz. 2011. Health effects of energy drinks on children, adolescents, and young adults. Pediatrics. 127: 511-528.

Thompson, M., S. L. R. Ellison and R. Wood. 2002. Harmonized guidelines for single-laboratory validation of methods of analysis (IUPAC technical report). Pure Appl. Chem. 74: 835-855.

Trabulo, D., S. Marques and E. Pedroso. 2011. Caffeinated energy drink intoxication. Emerg. Med. J. 28: 712-714.

Urfer, P., M. R. Mayol, L. D. Belingheri, F. Marx and M. J. J. Janssens. 2002. Inheritance studies of caffeine and theobromine content of Mate (llex paraguariensis) in Misiones, Argentina. Euphytica. 126: 203-210.

Van Zyl, J. M., B. Derendinger, H. I. Seifart and P. Van der Bijl. 2008. Comparative diffusion of drugs through bronchial tissue. Int. J. Pharm. 357: 32-36.

Wang, L. Y., K. Wei, Y. W. Jiang, H. Cheng, J. Zhou, W. He and C. C. Zhang. 2011. Seasonal climate effects on flavanols and purine alkaloids of tea (Camellia sinensis L.). Eur. Food Res. Technol. 233: 1049-1055.

Wu, F., R. Liu, X. Shen, H. Xu and L. Sheng. 2019. Study on the interaction and antioxidant activity of theophylline and theobromine with SOD by spectra and calculation. Spectrochim. Acta A Mol. Biomol. Spectrosc. 215: 354-362.

Xu, K., D. G. Di Luca, M. Orrú, Y. Xu, J. F. Chen and M. A. Schwarzschild. 2016. Neuroprotection by caffeine in the MPTP model of Parkinson's disease and its dependence on adenosine A2A receptors. Neuroscience. 322: 129-137.

Yang, X. R., C. X. Ye, J. K. Xu and Y. M. Jiang. 2007. Simultaneous analysis of purine alkaloids and catechins in Camellia sinensis, Camellia ptilophylla and Camellia assamica var. Kucha by HPLC. Food Chem. 100: 1132-1136.

Zacharis, C. K., F. S. Kika, P. D. Tzanavaras and K. Fytianos. 2013. Development and validation of a rapid ultra high pressure liquid chromatographic method for the determination of methylxanthines in herbal infusions. J. Chromatogr. B Anal. Technol. Biomed. Life Sci. 927: 218-222.

Zielinski, A. A. F., C. W. I. Haminiuk and T. Beta. 2016. Multi-response optimization of phenolic antioxidants from white tea (Camellia sinensis L. Kuntze) and their identification by LC-DAD-Q-TOFMS/MS. LWT Food Sci. Technol. 65: 897-907. 